\title{
On the morpho-syntax of possessive constructions
}

Judy B. Bernstein

\section{(2) OpenEdition}

\section{Journals}

Édition électronique

URL : http://journals.openedition.org/rlv/1364

DOI : $10.4000 /$ rlv. 1364

ISSN : 1958-9239

\section{Éditeur}

Presses universitaires de Vincennes

\section{Édition imprimée}

Date de publication : 1 décembre 2005

Pagination : $55-76$

ISBN : 2-84292-176-3

ISSN : 0986-6124

\section{Référence électronique}

Judy B. Bernstein, «On the morpho-syntax of possessive constructions », Recherches linguistiques de Vincennes [En ligne], 34 | 2005, mis en ligne le 22 décembre 2006, consulté le 21 avril 2019. URL : http://journals.openedition.org/rlv/1364 ; DOI : 10.4000/rlv.1364 


\author{
Judy B. BERNSTEIN \\ William Paterson University
}

\title{
ON THE MORPHO-SYNTAX OF POSSESSIVE CONSTRUCTIONS
}

\begin{abstract}
Possessive constructions in English, Spanish, and French differ in several ways. This article considers variation in word order, in the expression of agreement, and in the appearance of a preposition. The article generalizes to Spanish and French Bernstein \& Tortora's (2005) analysis of English possessive constructions, particularly the idea that the prenominal possessive constructions are distinct from the postnominal ones. All three languages display a prenominal possessive form that cannot co-occur with an article, supporting the idea that these forms must (eventually) occupy a DP-internal position. Postnominal possessive constructions display various patterns crosslinguistically. That of is required in English is consistent with the idea (see Kayne, 1993) that the movement assumed is DP internal. This also applies to Spanish and French possessive constructions with lexical DPs, which display $d e$. In Spanish, no preposition appears with postnominal possessive pronouns, which display properties of predicative adjectives. The analysis assumes a reduced relative structure with a possessive adjective and suppressed C (not D). In French, à appears with a non-possessive pronoun. Nevertheless, there is some support for the idea that the French construction is derived parallel to the English one.
\end{abstract}

\section{KEY-WORDS}

Possessives, adjectives, pronouns, agreement, partitive genitive, morphological complexity, preposition. 


\section{Introduction*}

Possessive constructions in English, Spanish, and French differ in several interesting ways. In this paper I consider variation in word order, in the expression of agreement, and in the appearance of a preposition. This variation will be examined within a particular language, as well as crosslinguistically.

In terms of word order, all three languages display prenominal possessive pronouns, as illustrated in (1).
a. your friend
b. tu amigo (Spanish)
c. ton ami
(French)

All three languages may additionally express possession via a construction containing a postnominal pronominal form, as in (2), or a full DP (here, a proper name), as in (3) ${ }^{1}$.
a. a friend of yours
b. un amigo tuyo
(Spanish)
c. un ami à toi
(French)
a. a friend of Mary's
b. un amigo de María (Spanish)
c. un ami de Marie (French)

Several observations can be made : a) For English and Spanish, the prenominal possessive pronouns are morphologically 'less complex' than the postnominal ones (the postnominal forms in contemporary French are strong pronouns that also appear in non-possessive contexts, and are not adjectival in nature $)^{2}$; b) the English and French postnominal constructions involving a pronoun require a preposition (of $v s \grave{a}$ ), absent in Spanish ; c) the English, Spanish, and French postnominal constructions involving full DPs all require a preposition (of/de), but only English further requires a marker $(-s)$ on the possessor. The analysis I develop addresses these similarities and contrasts.

The paper is organized as follows. Section 2 reviews Bernstein \& Tortora's (2005) analysis of English possessive constructions, which I will then extend to Spanish and French. Section 3 examines prenominal possessive pronouns in Spanish and French from the perspective of Cardinaletti's (1998) work on this topic. Unlike Cardinaletti, I do not conclude that Spanish and French pattern alike, but nevertheless retain her basic distinctions between 'weak' (including 'clitic') and 'strong' possessive pronominal forms. Section 4 compares postnominal possessive constructions in Spanish and French, including differences in morphological complexity between pre- and postnominal forms. I discuss differences between pre- and postnominal 
possessives in Spanish and the alignment of the postnominal forms with predicative adjectives. In order to tease apart the facts, I will distinguish between postnominal possessive pronouns and postnominal full DP possessives in these languages, which are compared to English. Section 5 provides a summary of the analysis and some concluding remarks.

\section{Possessive Constructions in English}

I begin by reviewing Bernstein \& Tortora's (2005) recent approach to possessive constructions in English, which appeals to differences between prenominal and postnominal (partitive genitive) possessive forms. That analysis addresses, among other things, the fact that prenominal DP possessives (4a), postnominal DP possessives (4b), and postnominal possessive pronouns (4c) all exhibit final $-s^{3}$.
a. Mary's book
b. a book of Mary's
c. a book of theirs

In contrast, prenominal possessive pronouns exhibit singular $-s(5 a)$ or plural $-r(5 b)^{4}$.
a. his, its answer
b. their, your answer

Bernstein and Tortora observe that the $-s /-r$ alternation in the possessive pronominal domain in (5) matches that of the $-s /-r$ alternation in the copular be domain. Notice that the copular forms in (6) are homophonous with the possessive forms in (5).

a. he's, it's nice

b. they're, you're nice

Based on these and other properties, Bernstein \& Tortora (see also den Dikken, 1998, 1999) propose the structure in (7) (their (9)) for English possessive pronouns, which capitalizes on similarities with the clausal copula structure $^{5}$. 
(7)

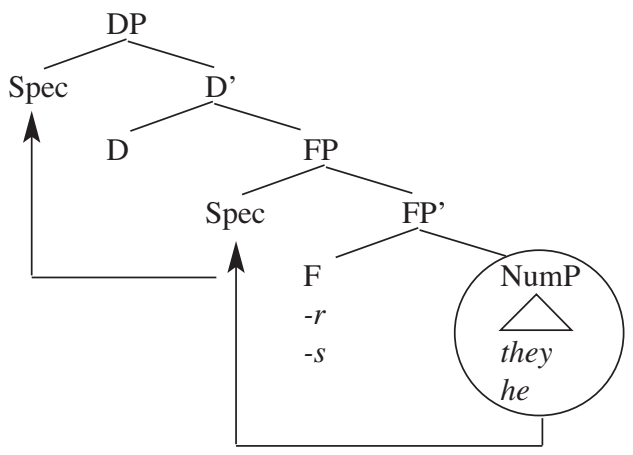

In this structure, the copula $(-s /-r)$ is the head of an FP projection and the NumP pronoun raises from the complement position to Spec,FP and then Spec,DP, forming the possessive pronoun (their, his $)^{6}$. If this analysis is on the right track, the agreement morphology visible on the possessive forms is copular number agreement and there is no possessive morphology per $\mathrm{se}^{7}$.

The coordination facts in (8) and (9) (Bernstein and Tortora's (16) and (15), respectively) argue that possessive pronouns and full DP possessives are syntactically distinct.
a. *we and their house
(cf. our and their house)
b. *he and your house
( $c f$. his and your house)
a. Jack and Jill's house
b. Jack and the boy's house

In particular, the facts in (8) show that the pronoun and $-s /-r$ marker form a constituent; those in (9) show that the full DP and $-s$ marker do not. This is because a single agreement marker per coordination is unacceptable with the pronouns, yet completely felicitous with the full DPs ${ }^{8,9}$.

Bernstein \& Tortora's (2005) internal structure of the larger possessive DP, a modification of Kayne's (1993 ; based on Szabolcsi, 1981 ; 1983) structure for possessives, is illustrated in (10) (their (19)). (Note that the DP from (7) occupies Spec,FP in (10).) This structure yields the prenominal DP possessive (Mary's friends) and possessive pronoun (their friends) straightforwardly. It also yields the postnominal possessive (friends of Mary's/theirs). I return to the postnominal possessive below. 
(10)

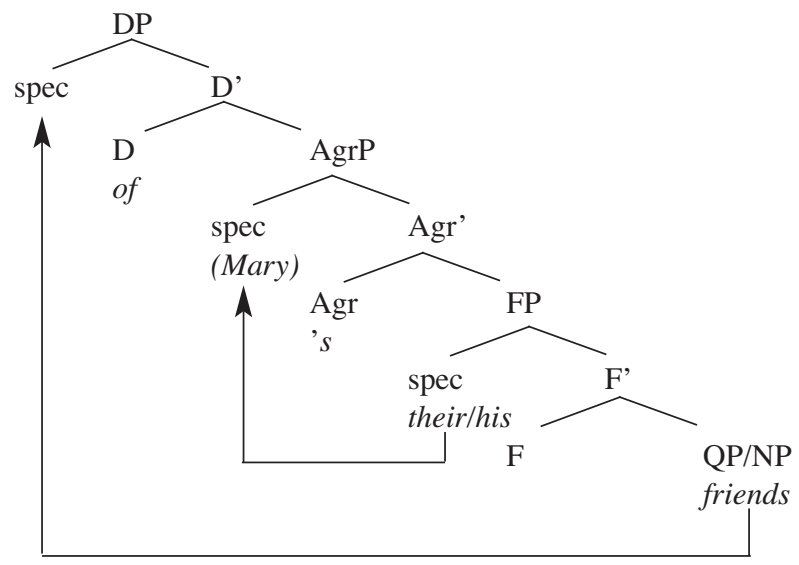

An important difference between this structure and that of Kayne's (1993) is that the one in (10) incorporates a positional difference between the pronoun and the full DP (an application of Cardinaletti's 2002 proposal for the CP domain) ${ }^{10}$. This accounts for the fact that the Agr head ('s) is present when the possessor is a DP like Mary or the woman (11a), but not when the possessor is a pronoun $(11 \mathrm{~b})^{11}$.

(11) a. Mary's/the woman's friend

b. *their's friend

Although their's is not possible as a prenominal possessive form, it does appear as a partitive genitive, as shown in (12a). In this construction, the pronouns pattern with the full DPs, as shown in (12b).

a. friends of theirs

b. friends of Mary's $\underline{\mathrm{s}}$ the woman' $\underline{\mathrm{s}}$

According to Bernstein and Tortora, the partitive genitive facts are generated by the structure in (10) in the following way. The QP/NP friends raises to Spec,DP, triggering of in D (Kayne, 1993) ${ }^{12}$. A strict adoption of Kayne's original formulation could take the Case-licensor of to require an NP/DP in its vicinity to discharge its Case to. The pronoun their would raise to Spec,AgrP to serve as the recipient of of's Case. Alternatively, a more current approach might be to say that the partitive genitive 's in Agr has an EPP feature, which is satisfied by movement of the pronoun their to its specifier. Either way, under this analysis the (possessive) $-s$ in (12a) has the same source as that in (12b).

In the next two sections, I show how the proposal for English may be extended to Spanish and French. The analysis builds on Cardinaletti's (1998) work on the syntactic status of possessive pronouns cross-linguistically. 


\section{Prenominal Possessive Pronouns in Spanish and French}

According to Cardinaletti (1998), possessive pronouns divide crosslinguistically into 'deficient' or 'strong', labels that make reference, at least in part, to their morphological form (see Cardinaletti \& Starke, 1994). Across Romance languages, the deficient forms are associated with the prenominal position and reduced morphological complexity; the strong forms are associated with the postnominal position and a more complete/robust morphological form. For Cardinaletti, the deficient forms may be clitics (heads) or prenominal specifiers below D. The 'strong' possessives are also specifiers which remain in their base position (see also Picallo, 1994). The clitics presumably raise to D (Giorgi \& Longobardi, 1991 ; Bernstein, 2001 ; Cardinaletti, 1998).

According to Cardinaletti, French and Spanish prenominal possessives exhibit the properties of true clitics and Italian prenominal possessives exhibit the properties of 'weak' (but not clitic) forms. She claims that the Spanish and French possessive forms may not be coordinated or focalized, which would provide support for the idea that the prenominal possessive elements are clitics in these languages. The judgments that Cardinaletti reports are provided in (13) for Spanish and (14) for French.

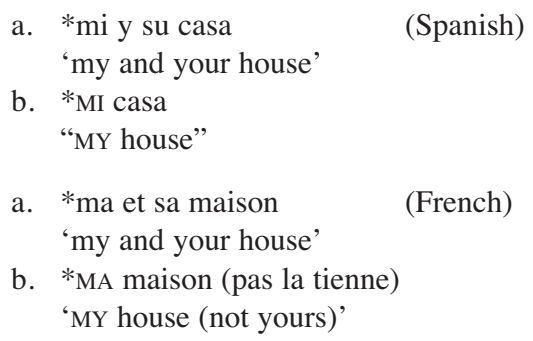

The Spanish speakers I consulted with seem to be in basic agreement with Cardinaletti's facts (but the judgments may not be as clean as Cardinaletti seems to imply). The French judgment reported by Cardinaletti for coordination in (14a) was not consistently reported by the speakers I consulted : while some speakers could not imagine coordinating these forms, others found it quite possible ${ }^{13,14}$. The speakers I consulted generally reported that focalization of possessive pronouns, as in (14b), is grammatical ${ }^{15}$. (I leave open here the issue of whether the differences represent regional or individual speaker variation.) The facts that emerge cast some doubt on the clitic approach to prenominal possessives in French ${ }^{16}$.

The English prenominal possessives, which are also apparently deficient (recall (1a) $v s$ (2a)), clearly do not exhibit the properties of clitics. English prenominal possessive pronouns may be coordinated (15a) and focalized (15b). 
a. your and their house

b. MY house

Cardinaletti (1998 : 27 and fn. 14) claims that English possessive pronouns are deficient ${ }^{17}$, but leaves open the question about whether they are clitics or specifiers. Given the approach to these forms developed in Bernstein \& Tortora (2005 ; recall (7) and (10)), I will not take the English possessive pronouns to be clitics, but rather 'weak' XP possessives. It is worth mentioning that one property that these prenominal 'weak' forms (both clitics and XPs) seem to have in common cross-linguistically is the inability to appear without an overt noun.

It is interesting to observe that neither the English, Spanish or French prenominal forms may co-occur with an article, which would be consistent with the idea that the forms occupy the D position. However, as Cardinaletti observes, this fact alone does not establish that they are clitic (D) forms. She suggests that they may, in fact, occupy a high spec (below D) position. Instead, I pursue the idea that French and English prenominal possessives are weak XPs and that they may raise to Spec,DP, which would explain the absence of a co-occurring definite article (under the assumption that Spec,DP and $\mathrm{D}$ cannot be filled simultaneously, at least in the languages under discussion). This latter idea would also make sense in terms of interpretation and function, since the possessive forms under consideration render a DP definite. A natural assumption to make (based on a proposal originally made for proper names in Longobardi, 1994) is that the definiteness features of D are checked by either a head in D (definite article, clitic possessive pronoun) or through specifier-head agreement with a 'weak' possessive pronoun in Spec,DP ${ }^{18,19}$. I return to D and its (definiteness) features in section 4.

The difficulty of coordination and focalization with the Spanish forms (in (13)) supports distinguishing Spanish from English. The fact that some French speakers allow coordination, and most seem to permit focalization, suggests that French may have a status like English, or perhaps a status intermediate between Spanish and English. (This parallelism to English will also be relevant for the discussion of the postnominal possessives in section 4.) Because although French historically had postnominal forms corresponding to the Spanish ones in (2b), in the contemporary language these forms no longer co-occur with overt nouns (la tienne, the your, 'yours' ; *la maison tienne, the house your). The equivalent of (2b) in contemporary French is expressed with a preposition (a) and a non-possessive form, so in some respects similar to the English pattern illustrated in (2a) (see section 4 for further discussion of the French pattern).

Generalizing Bernstein and Tortora's structure for English (recall (10)), I claim that the possessive prenominal clitic $m i$ (but not the full form míos) in a language like Spanish raises to $\mathrm{D}$, as illustrated in $(16)^{20}$. The 
French equivalent (mes, 'my') would originate in the same position, but its landing site might more appropriately be Spec,DP, at least for the relevant speakers.

(16)

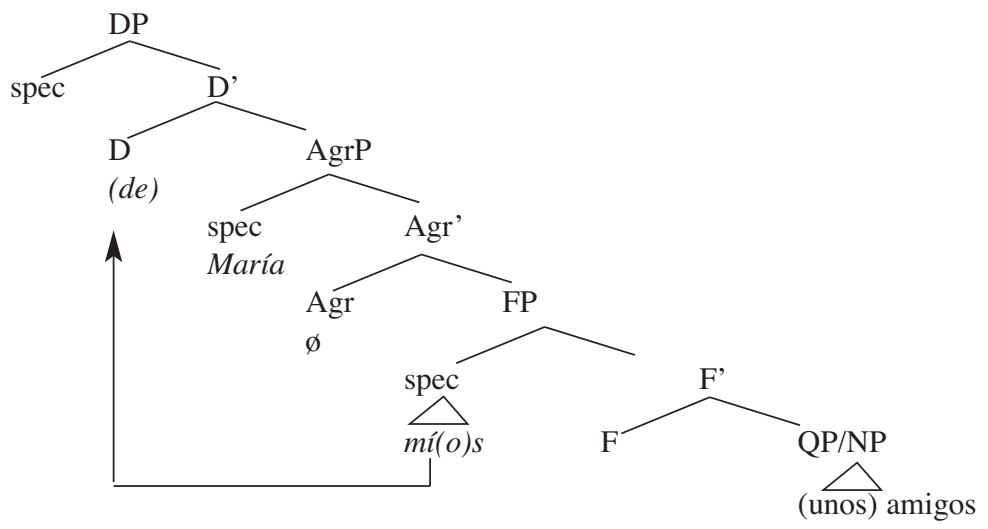

It is interesting to note that a structure very similar to the one in (16) is proposed in Sánchez (1996: 197, (393)) for possessive structures in Andean L2 Spanish. Further, Liliana Sánchez (personal communication) points out that Andean L1 Spanish may provide some independent support for this type of approach to possessives. Consider the examples in (17)-(18) (examples due to Liliana Sánchez) ${ }^{21}$.

de María su amigo of Mary her friend

'Mary's friend'

su amigo de María her friend of Mary

(Andean Spanish)

'Mary's friend'

(Andean Spanish)

Observe that in standard varieties of Spanish Mary's friend would be expressed with the word order of (18) and the definite article (i.e., el amigo de María).

At first glance, the example in (17) could correspond directly to the structure in (16) and so would not involve movement of the NP or the possessive pronoun. One question that arises, however, is how de appears in (17), since there is nothing overt triggering its appearance. A possible solution would be to posit a pro in Spec,DP, which would substitute for the XP movement to this position found in standard Spanish or English. Something along these lines is in fact proposed in Sánchez (1996 : 197, (393)) for her bilingual Spanish speakers, although for Sánchez $d e+\mathrm{N}$ is a constituent occupying a specifier position ${ }^{22}$. 
Liliana Sánchez (personal communication) notes Muysken's (1984 : 112) idea that examples like (17) in L2 Andean Spanish might involve leftdislocation of de María. If the dislocation approach to the L2 facts turns out to be correct, that still leaves open the question about L1 Andean Spanish, which exhibits this same surface word order. If de María is indeed leftdislocated in L1 Andean Spanish in examples like (17), the landing site would presumably be Spec,AgrP, and in this way equivalent to English Mary's. This would still be compatible with the proposal that pro is merged in Spec,DP. As proposed by Sánchez (1996 : 196), this pro would be coindexed with $s u$, which she takes to be a person agreement marker.

If Sánchez is correct that $s u$ in these examples is an agreement marker, and not a possessive form of the standard Spanish variety, this would explain why $s u$ cannot itself raise (to D) in an example like (18). In that case, this example would be derived parallel to standard Spanish examples like (3b) or the alternative with a definite article ${ }^{23}$.

Without more data on L1 Andean Spanish, it is difficult to know whether (17) or (18) represents the more basic word order in this variety. If it turns out that (17) is in some sense more basic (and so not involving leftdislocation), it would be tempting to match (17) directly to the structure in (16). And then the relationship between (17) and (18) would very closely approximate that of a language like English, where I've taken the possessorpossessed word order to be more basic and the possessed-possessor order to be derived from it. In that case, Andean Spanish would be a rather exceptional Romance language.

Interestingly, Liliana Sánchez informs me that the Andean Spanish example in (19) is not grammatical.

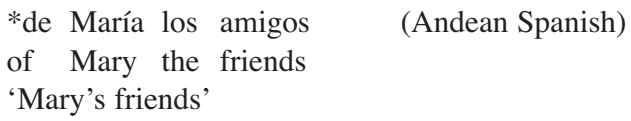

Two possible explanations come to mind. One is that the appearance of the definite article illicitly duplicates the definiteness already supplied by the proper name (as it would in a language like English : *Mary's the friends). The plausibility of this explanation would be enhanced if (17) (rather than (18)) represents the underlying word order. This is because it isn't clear what would block the appearance of the definite article in (19) given an underlying word order like los amigos de María, which is grammatical in standard varieties of Spanish. Another consideration with respect to (19) could be the absence of an appropriate coindexed agreement marker ( $c f$. $s u$ in (17)) necessary for licensing pro in Spec,DP.

In this section, I have suggested that the structure originally developed for English prenominal possessive pronouns in Bernstein \& Tortora (2005) be 
generalized to Romance languages like Spanish and French (recall (16)). In particular, I have adopted Cardinaletti's (1998) idea that the prenominal possessive pronouns in Spanish are clitics and raise to D. This is consistent with the fact that these forms are often morphologically defective and resist coordination and emphasis. Although Cardinaletti adopts the same analysis for the French forms, I have not found that native speaker judgments clearly support the clitic analysis. If anything, French prenominal possessive pronouns seem to pattern more with the English forms, which I have assumed to be 'weak' XPs. Interesting issues are raised by possessive constructions in Andean Spanish, where word order patterns may line up with the structure quite naturally. However, more research into this variety of Spanish must be conducted before any definitive conclusions can be drawn.

Finally, it is worth noting that the prenominal possessive forms in languages like Italian, where the possessive form co-occurs with the definite article, would also be 'weak' XPs in Cardinaletti's system. However, since they are adjectival in nature and co-occur with a definite article, these 'weak' XPs would not raise into the DP projection ${ }^{24}$.

\section{Postnominal Possessives and the (non)appearance of a Preposition}

The Spanish example in (2b) illustrates that a postnominal possessive (adjectival) form is morphologically more complex than a prenominal one (1b). The pre-/postnominal contrast for Spanish is repeated in (20). Observe that Paduan also exhibits a contrast between the prenominal and postnominal forms, as illustrated in (21) (example from Cardinaletti, 1998), but recall that this prenominal form, which co-occurs with the definite article, is not taken to be a D head.
a. tu amigo
'your friend'
(Spanish)
b. un amigo tuyo
'a friend of yours'
a. el me libro 'my book'
b. el libro mio 'MY book'
(Paduan)

Besides the tendency towards greater morphological complexity, the postnominal forms in many Romance languages exhibit a clustering of other properties that support Cardinaletti's treatment of them as 'strong' forms (French exhibits a different pattern; see section 3 and below). The relevant properties of the strong forms, which also characterize predicative adjectives, are listed in (22). 
(22) 'Strong' forms :
a. may be coordinated
b. may be modified
c. may appear with an elided noun
d. may be focalized
e. may/must appear with an overt determiner
f. may appear as a predicate

For Cardinaletti (1998: 18) these strong forms remain in their base position after N-raising (Cinque, 1994). Bernstein (2001; see also 1997) argues instead that the DP-final position of the possessive pronouns must be the result of XP movement ${ }^{25}$.

Bernstein's XP-raising analysis relies on two basic facts about the postnominal possessive forms : a) In addition to following the noun directly, they may also follow adjectival modifiers and noun complements, as illustrated in (23) ; b) the DP-final position (unlike the prenominal position) may be associated with a focus interpretation, as in $(24)^{26,27}$.

$$
\begin{aligned}
& \text { un libro de poesía mío } \\
& \text { a book of poetry my } \\
& \text { 'a book of poetry of mine' }
\end{aligned}
$$

el amigo (viejo)
SUYO

The idea developed in Bernstein (2001) is that the DP-final focus position in Romance is derived by XP-raising, akin to scrambling in the clause ${ }^{28}$. In other words, the material that is scrambled leftward is not focused. Instead, it is the element stranded DP-finally that receives the focus interpretation. I will adopt the basic idea that the raising involved in these constructions is XP raising ${ }^{29}$.

In addition to lacking an equivalent to the scrambling construction found in Romance, English disallows the appearance of the definite article in the postnominal possessive construction. Consider the facts in (25) and (26).
a. *the old friends of hers/Mary's ( $c f$. some old friends of hers)
b. the old friends of hers/Mary's that you know
a. her/Mary's old friends
b. ?*her/Mary's old friends that you know

Building on observations and analysis in Kayne (1994:105), I take the ungrammaticality of (25a) to reduce to an offending the, which would have a relative clause source. This is supported by the fact that the same the is licit in $(25 \mathrm{~b})$, which contains a restrictive relative clause but is otherwise identical to (25a). The facts are exactly reversed in (26), as they should be if the relative 
clause approach is valid for (25). Specifically, (26a) (cf. (25a)) is fine as a simple possessive DP (without the) and (26b) is ungrammatical because the head of the relative clause is not introduced by the.

The underlying structure Kayne (1993 and subsequent work) assumes for relative clauses is the one in (27), where D takes $\mathrm{CP}$ as a complement.

[D [CP]]

More precisely, the relative clause structure involves raising of the XP 'head' of the relative to Spec,CP. An example like (25b) would be schematically represented as in (28), where I have abstracted away from the movement internal to old friends of hers.

$\left[_{\mathrm{D}}\right.$ the $\left[_{\mathrm{CP}}[\text { old friends of hers }]_{\mathrm{i}}\left[_{\mathrm{C}}\right.\right.$ that $\left[_{\text {IP/AgrP }}\right.$ you $\left[_{\mathrm{I} / \mathrm{Agr}}\right.$ know $\left.\left.\left.\left.\left.\ldots\left[_{\mathrm{NP}}[]_{\mathrm{i}}\right]\right]\right]\right]\right]\right]$

Although English does not allow the appearance of the definite article in cases like (25a), the parallel example in Spanish is fine (with scrambling assumed), as seen in (24). I take this to indicate that these Spanish examples, but not the English ones, involve a (reduced) relative structure ${ }^{30}$. In other words, the Spanish possessives, but not their English equivalents, involve a structure with a (verbal) IP, even though the entire phrase, which may serve as an argument, must be a DP. Observe that the relevant adjectives and modifiers are predicates (in (23) and (24)), supporting the basic reduced relative approach.

The internal structure of an example like (24) would be as in (29), where I am ignoring the issue of whether XP-raising or N-raising derives the noun-adjective order ${ }^{31}$.

$$
\left[_{\mathrm{D}} \text { el }\left[_{\mathrm{CP}}[\text { amigo viejo }]_{\mathrm{i}}\left[\left[_{\mathrm{C}} \varnothing\left[_{\mathrm{IP} / \mathrm{AgrP}} \text { suyo }\left[_{\mathrm{I} / \mathrm{Agr}}\left[{ }_{\mathrm{NP}}[]_{\mathrm{i}}\right]\right]\right]\right]\right]\right]\right.
$$

Note that (29), as a reduced relative, allows for suppression of C.

This analysis now provides an explanation for the distinction between the English and Spanish examples in (2a) and (2b). Recall that with postnominal possessive pronouns, English requires of and Spanish prohibits de. As illustrated in the structure in (10) for English, of is triggered in D when $\mathrm{QP} / \mathrm{NP}$ raises to its specifier. Under this different but still parallel derivation for (certain) Spanish possessive constructions in (29), which is supported by the relative clause facts distinguishing the two languages, the absence of $d e$ is not only NOT problematic, but even expected. That is because the $\mathrm{C}$ head that is suppressed would never correspond to de in Spanish, but rather to a relative pronoun (e.g. que, con quien).

The current approach may also help explain the difference in morphological complexity between pre- and postnominal forms. Recall from the introduction and examples (20)-(21) the observation that the prenominal forms in Spanish and other Romance languages tend to be morphologically 
less robust than the postnominal forms. In Romance languages like Spanish (also Paduan), it is gender that is robustly expressed on the postnominal form, but sometimes lost on the prenominal form. English also exhibits an alternation. If the analysis in Bernstein \& Tortora (2005) for English is on the right track, the postnominal form exhibits (singular) number agreement that is absent on the prenominal forms, which only display copular $(-s /-r)$ agreement. In English, this extra morphological complexity (the expression of number agreement on the postnominal forms) is triggered on the pronoun occupying the specifier of an Agr head in (10). So the greater morphological complexity on the postnominal forms in English is due to a SECOND agreement relation. In other words, the postnominal possessive pronoun undergoes copular agreement (recall (7)), IN ADDITION TO singular/plural number agreement (after XP-raising to Spec,Agr) with Agr.

Apparently similarly, the expression of number and gender on possessive pronouns in Spanish is triggered on the specifier of an Agr head. However this AgrP (see (29)), unlike the AgrP for English (in (10)), is sentential and the morphological agreement inventory for Spanish includes both number and gender. The DP-internal agreement assumed for the prenominal possessives (recall (16)) is mediated through a functional head $\mathrm{F}$. The hypothesis I will entertain, subject to further research, is that this DPinternal $\mathrm{F}$ head is for some reason more prone to 'defective' agreement than its sentential-Agr counterpart. If this approach is on the right track, the explanation for the pre- $v s$ postnominal differences in morphological complexity in a language like Spanish may reduce to differences between DPinternal and sentential agreement ${ }^{32}$.

Another consideration in distinguishing the pre- $v s$ postnominal possessive forms in Spanish is the determination of the salient information contributed by the forms. With the prenominal forms, which are morphologically defective and cannot appear with a co-occuring definite article, the expression of person (corresponding to the possessor) is salient. In this way, the person marker (e.g. $m-, t^{-}$; see Kayne, 2000) identifies the DP-external referent. I suggest that it is person that is associated with D, which doesn't preclude definiteness being derivationally related to $\mathrm{D}^{33}$. In this way, I maintain Longobardi's (1994) insight that only DPs can be arguments, with the additional property that $\mathrm{D}$ encodes person features ${ }^{34}$.

With the postnominal possessive forms, which behave like predicative adjectives, what is salient is the predication relationship established with a noun. This relationship should account for the more robust display of nominal agreement features (i.e., gender). Additionally, the predication relationship with the noun (absent with the prenominal possessives) connects the adjectival forms to the features seen in (22). In particular, a noun may be absent/elided but a determiner (in the case of an argument) may not. 
The final issue to address is how to unify examples like (3a) and $(3 b, c)$, repeated here in (30) and (31).

(30) a friend of Mary's
a. un amigo de María
(Spanish)
b. un ami de Marie
(French)

First, keep in mind that these examples, unlike the previous ones, involve full DP possessives, not possessive pronouns. Second, the English, Spanish, and French constructions match in that they all require a preposition. The fact that Spanish and French exhibit a preposition equivalent to the English one, and that this preposition de never appears as a relative pronoun in Spanish or French, supports the idea that (31) is not a reduced relative, but rather a nonsentential (DP) construction corresponding to the English one seen earlier in examples like those in (12). I will assume therefore that the derivation attributed to those examples (see (10)) must be the relevant one for Spanish and French examples like (31).

So for English, Spanish, and French, the NP (friend/amigo/ami) raises to Spec,DP, triggering oflde in D (recall structures in (10) and (16)). This yields un amigo de María (in Spanish and French), whose form is identical to the English one except for one small detail. English a friend of Mary's requires the 's marker on Mary. This means that the Agr head in (10) (or (16)) must be spelled out in English, but cannot be spelled out in Spanish or French. Although I have no real explanation for why that would be, I suspect that the answer reduces to differences in Case-licensing in English vs Spanish and French.

So far, I have looked at postnominal full DP possessives in English, Spanish, and French ((30) and (31)), which I have claimed to be essentially parallel. Recall, however, that English and Spanish differ with respect to the postnominal possessive pronouns, which are adjectival in Spanish but not in English, where of is triggered. I attributed these distinctions to different sources for the two forms : a DP-internal source for English and a sentential (reduced relative) source for Spanish. I turn now to French, a language that displays a pattern somewhat different from Spanish and English.

Recall from section 3 that contemporary French no longer has postnominal (adjectival) possessive pronouns. Instead, the language resorts to a strategy whereby the possessive function is expressed via a dative preposition (à) plus non-possessive pronoun, as in $(32)^{35}$.

$$
\begin{aligned}
& \text { un ami à moi } \quad \text { (French) } \\
& \text { a friend to me } \\
& \text { 'a friend of mine' }
\end{aligned}
$$


Since this pronoun is clearly not adjectival (unlike the Spanish forms) it is highly unlikely that the relative clause analysis attributed to the Spanish postnominal possessive pronouns applies here. Can the analysis adopted for English generalize to these French cases? I claim that the analysis for English a friend of mine (recall (10)) does indeed extend to French. However, the two differences between the English and French constructions must be explained. These are : a) the prepositions involved (of $v s a$ ) do not match ; b) the English pronoun formed, although not marked 'possessive' in any obvious way, is still reserved for possessive use ; the French form is a regular (non-possessive) lexical pronoun.

The French word order in (32) would result from XP movement of the $\mathrm{QP} / \mathrm{NP}$ un ami to Spec,DP, triggering a preposition in D. Some indirect support for taking French $a$ to correspond to D in (10), parallel to English of (and French and Spanish de), comes from Walloon, where there is apparently dialectal variation as to whether the composite preposition d'à appears with a regular (non-possessive) lexical pronoun or with a strong possessive pronoun. In particular, the non-possessive pronoun is used in central and western Walloon dialects (33a) and the strong possessive pronoun in eastern and southern dialects (33b) (Li waibe del croejhete walone, 'On-line Walloon grammar').

a. ci lîve la, c'est da mi

b. ci lîve la, c'est da mine

that book there, it is $d a \mathrm{me} / d a$ mine

'that book is mine'

The example in (33a) presumably patterns with French (recall (32)), and the example in (33b) with English a friend of mine. I suspect that the composite preposition plays a role in the attested variation across Walloon dialects : the à component yields the French pattern of (32) and the de component yields the English pattern (with de equivalent to English of). The derivations for the two would therefore be equivalent, the preposition responsible (in a way I cannot yet make explicit) for the accompanying pronominal form.

A remaining question is why this non-possessive pronominal form would be merged in Spec,FP. While I don't have a definitive answer to this, it must also be assumed for English her and other accusative possessives found in UK varieties of English (see note 4). Although an exceptional form for English (so unlike the completely general French pattern), accusative her serves as the base for the prenominal and postnominal possessive forms in English ${ }^{36}$. 


\section{Conclusions}

The goal of this paper has been to unify certain apparently disparate properties found in possessive constructions in English and two Romance languages, Spanish and French. To that end, I have extended Bernstein \& Tortora's (2005) analysis of English possessive constructions to these languages. In particular, I have generalized to Spanish and French the idea that certain prenominal possessive constructions are structurally distinct from the postnominal ones.

I have followed Cardinaletti's (1998) three-way distinction for possessive pronouns ('weak' clitics, 'weak' XPs, and 'strong' XPs). The prenominal possessive pronouns in Spanish overwhelmingly display properties of D clitics. Speakers' judgments indicate that the French forms, which Cardinaletti also categorizes as D clitics, are more accurately treated as weak XPs. English prenominal possessives would also belong to this weak XP class, judging from the suggestion in Cardinaletti (1988) and discussion found in Bernstein \& Tortora (2005).

The explanation for the difference in morphological complexity between pre- and postnominal forms takes two different paths. In English, the postnominal forms participate in (and then display overtly) an extra agreement relationship. In Spanish, the DP-internal agreement for the prenominal forms can be more 'defective' than the sentential (Agr) agreement of the postnominal forms. In addition, the prenominal forms, as D elements, are primarily involved in the expression of the DP-external person features of a referent (the possessor). The postnominal forms are adjectival in nature and are primarily involved in a predication relation with the noun. French prenominal possessive forms cannot be compared to the postnominal ones because the postnominal forms are expressed via a non-possessive pronoun.

The (non)appearance of the preposition in postnominal possessives varies cross-linguistically. In English, the preposition is always triggered (in otherwise empty D) when QP/NP raises to the specifier of DP. De is never triggered in Spanish postnominal possessive pronoun constructions because these involve a reduced relative structure with a possessive adjective and suppressed C (not D). The French construction is derived parallel to the English one, except that the preposition triggered in $\mathrm{D}$ is $a$ and the pronoun is non-possessive. Postnominal full DP possessives are remarkably similar across the three languages (of/de displayed in all) supporting their uniform treatment. The extra requirement that 's appear with the possessor in English may be reduce to issues of Case-licensing.

It is my hope that the patterns discussed and analyses developed will prove relevant for other (Romance) languages as well. 


\section{NOTES}

* I am grateful for feedback from two anonymous reviewers as well from audiences at the Linguistic Symposium on Romance Languages at the University of Indiana, Bloomington in April 2003, Rutgers University in January 2003, and at the Lisbon Workshop on Agreement, held at the Universidade Nova de Lisboa in July 2003. I am especially indebted to Julie Auger, Johan Rooryck, and Viviane Déprez for French judgments, to Francisco Ordóñez for Spanish, and to Liliana Sánchez for discussion, data, and suggestions on (Andean) Spanish. The omissions, errors, and shortcomings are my own contribution.

1. I am ignoring here the possibility of $d e+$ full pronoun in Spanish (un amigo de ella, 'a friend of hers'), which presumably works like the full DP example in (3b) (see section 4 for analysis).

2. Morphological COMPLEXITy is used descriptively. In English, the postnominal forms exhibit final $-s$ but the prenominal forms don't. In Spanish, the postnominal forms display number and gender agreement ; the prenominal $\left(1^{\text {st }}, 2^{\text {nd }}, 3^{\text {rd }}\right)$ forms display only number agreement.

3. In fact, Bernstein \& Tortora (2005) argue that there is an alternation between possessive singular $-s$ and plural $-\varnothing$, as illustrated by regular possessives like girl's and girls' $\phi$. This pattern then matches that of singular and plural present tense verbal inflection (compare knows and know $\varnothing$ ). The limited and finite set of pronouns and irregular plurals exhibit possessive $-s$ exclusively (e.g., theirs, children's).

4. This glosses over the fact that sg. her does not exhibit -s. Bernstein and Tortora take her to be a suppletive form that is homophonous with the accusative ( $c f$. British us friends). My, which is also unmarked for sg./pl., is taken to fall outside the regular sg./pl. paradigm (see Kayne, 1989 for the idea that $1^{\text {st }} \mathrm{sg}$. $I$ is unmarked for number). 5. Another property common to both the copular forms and the possessive forms (discussed in Bernstein \& Tortora) is the availability of COPULA DELETION in varieties of AAVE : they nice ('they're nice'), they friend ('their friend').

6. The short vowel in the $3^{\text {rd }}$ person singular possessive (his) does not match the long vowel of the simple pronoun (he). See Bernstein \& Tortora (fn. 5) for discussion. 7. The structure in (7) incorporates ideas by Ritter (1995) and Déchaine \& Wiltschko (2002) that certain pronominal forms are NumPs or AgrPs.

8. Bernstein and Tortora (fn. 17) further illustrate the non-constituency of 's and a lexical noun (recall (9)). They consider the following example (drawn from Kayne, 1989 : 5), where 's does not form a constituent with the possessor the woman : the woman who I saw a picture of's daughter.

9. As Bernstein and Tortora note, the good examples in (8) are ambiguous, admitting either a distributive or collective reading, while those in (9) are unambiguously collective. For my purposes, it is sufficient here to compare the parallel (collective) readings, and assume some other analysis, irrelevant to present purposes, for the distributive reading also admitted in the good examples in (8) (but see Bernstein \& Tortora for a possible approach).

10. Bernstein and Tortora provide some independent motivation for the positional difference between pronoun and full DP. In particular, some Germanic languages (such as Norwegian and even varieties of UK English) exhibit co-occurrence of the two, 
with the full DP preceding the pronoun (e.g., Norwegian Per sitt hus, Per his house, 'Per's house'). In some languages, dative prenominal possessors may also appear (probably via movement) prenominally, as discussed by Szabolcsi (1983) for Hungarian.

11. According to Bernstein and Tortora, the movement of their to Spec,AgrP in (10), is triggered only by movement of the QP/NP friends, generating the postnominal possessive form theirs.

12. Although closer, Mary's does not raise to Spec,DP in the partitive genitive construction, probably because as a possessive it is the wrong type of nominal element.

13. A reviewer notes that the example in (14a) is ungrammatical for all speakers of French s/he knows. I have not found that to be the case, as stated in the main text.

14. Johan Rooryck (personal communication) provides the following attested examples from the internet : J'ai lu mon and son titre, 'I read my and his/her title'. ; Nous, soussignés, demandons qu'il ne soit administrés à moi-même et à mon époux, ni sang, ni dérivés du sang durant mon et son hospitalization, 'We, the undersigned, ask that no blood nor any derivative blood products be given to me or my spouse during my and his hospitalization'. A reviewer states that internet examples are not to be trusted. S/he suggests that the first example is ungrammatical and may have resulted from non-edited computer text, and that the second example, although ungrammatical in normal usage, is found in formal/legal discourse. I believe the variability in judgments for the French examples discussed here and in (14) suggests that Cardinaletti's depiction of the facts is oversimplified.

15. A reviewer notes that the licit focalization of the possessive pronoun in (14b) is also found with pronominal clitics in an example like : Je LA connais, 'I CL know'. 16. Cardinaletti's (1998) account of Kayne's (1975) DP-internal CLITIC DOUBLING facts in French (mon ami á moi, my friend to me, 'my friend'), with mon as a clitic, would then need to be recast. As suggested by Richard Kayne (personal communication), what is doubled may in fact be the $m$ - person marker, which itself may count as the clitic. This would be compatible with the idea that possessive mon, which is at least bi-morphemic, is itself not a clitic element.

Although standard Spanish does not seem to allow for doubling with possessive pronouns, the following Andean Spanish example (due to Liliana Sánchez, personal communication) indicates the possibility of doubling in this variety : $s u$ amigo de ustedes (your friend of you, 'your friend'). In this case as well, pronominal $s u$ is not necessarily a clitic (see discussion below (18)).

17. For Cardinaletti, both clitics and weak XPs are 'deficient' elements.

18. This approach to the English prenominal possessive pronouns would also apply to English prenominal possessives with proper names, such as (4a).

19. For languages like Italian, where the prenominal possessive forms co-occur with the definite article, Cardinaletti's lower Spec idea is plausible, because in these cases the possessive forms, as adjectives, would have no definiteness features to check in DP. Also note that Italian pre- (but not post-) nominal possessives, which cannot appear in isolation, would also be weak XPs.

20. The possessive adjective míos does not raise to Spec,DP because it is the wrong type of nominal element. 
21. Liliana Sánchez informs me that these examples are found among monolingual Spanish speakers of Quechua background. She gathered the data in the Central Andes of Peru.

22. In particular, Sánchez's (1996 : 101) structure involves a pro in PredP, a projection situated below DP that plays a role in licensing, through agreement, null NPs and the post-nominal position of extensional adjectives. The AgrP in (16) might correspond to something parallel, although it's not obvious how the pro would not be merged in that projection.

23. Andean Spanish su might in fact be ambiguous between an agreement marker and a possessive pronoun. This idea is supported by the fact that $s u$ appears in examples like (17) and (18), where it plays no role in definiteness, and also in examples where its function appears to be the same as in standard Spanish (e.g., su cabeza, 'his head'). Thanks to Liliana Sánchez for sharing these data and discussing their significance.

24. Further discussion of the prenominal (non-determiner) possessives may be found in Picallo (1994), Giorgi and Longobardi (1991), and Cardinaletti (1998).

25. This same general approach is also found in Sánchez (1995 and other work).

26. A reviewer points out that postnominal possessives cannot always follow de+N : *un amigo de España mío.

27. Roberto Zamparelli (personal communication) notes that although the postnominal possessive is generally associated with a focus interpretation in Italian, a neutral interpretation is obtained when the possessive pronoun is part of a coordination. In fact, the possessive may not appear prenominally in this case. Zamparelli provides the following example : un amico mio e di Maria ('a friend of mine and of Maria's'). This fact probably stems from a requirement for parallel structures in cases of coordination (see Bernstein and Tortora for some discussion of this for English).

28. English, unlike Romance, expresses DP-internal focus via contrastive stress, not position.

29. French DP-internal scrambling is more limited, applying in constructions with demonstrative reinforcers and descriptive adjectives (see Bernstein, 1997 ; 2001).

30. See Hoekstra (1999) for an application of this basic idea to Dutch nominalized infinitival structures.

31. I leave open the issue of the merger site of suyo, but see Picallo (1994) for a possible approach.

32. Even more striking than Spanish, eastern and central (but not southern) varieties of Walloon never display a gender alternation on prenominal possessive pronouns or definite articles, although gender is robustly expressed on indefinite articles and prenominal adjectives.

Something else to consider, however, is the fact that attributive (prenominal) adjectives in languages like German, Dutch, and Walloon display richer agreement than predicative forms appearing with the copula.

33. In this regard I have proposed that English th- forms, including the definite article the, display $3^{\text {rd }}$ person, which is associated with D (see Bernstein, to appear). A parallel idea is developed in Longobardi (2004). 
34. See Camacho and Sánchez (1996 : 163) and Sànchez (1996 : 197) for the relevance of 'person agreement' to Andean L2 Spanish forms. The potentially ambiguous nature of $s u$ in Andean L1 Spanish (see note 23) is undoubtedly relevant to the discussion in the main text.

35. This basic pattern holds across persons (moi, toi, nous, vous, etc.). Speakers report that this pattern is also possible with full DP possessives (e.g., un ami à Martin, 'a friend of Martin's') alongside the standard construction in (31b), but may have a more colloquial flavor.

36. The following colloquial English example, where an accusative appears as the first conjunct, may also be relevant : Me and John's friend visited last week (see Bernstein and Tortora for discussion).

\section{REFERENCES}

Bernstein, Judy B. (1997). Demonstratives and Reinforcers in Romance and Germanic Languages. Lingua 102 : 87-113.

Bernstein, Judy B. (2001).Focusing the 'Right' Way in Romance Determiner Phrases. Probus 13 : 1-29.

BernsteIn, Judy B. (to appear). English $t$ - Forms. To appear in a volume in the series Typological Studies in Language. Amsterdam: John Benjamin.

Bernstein, Judy B. ; Tortora, Christina (2005). Two Types of Possessive Forms in English. Lingua 115 : 1221-1242.

Camacho, José ; SÁnchez, Liliana (1996). De mi padre, su padre: The Syntax of Word Order Transfer and Person Agreement in Andean L2 Spanish. In Streamfellow, A., Cahana-Amitay, D., Hughes, E., \& Zukowski, A. (eds.), Proceedings of Boston University Conference on Language Development : 155-166. Somerville, MA. : Cascadilla Press.

Cardinaletti, Anna (1998). On the Deficient/Strong Opposition in Possessive Systems. In Alexiadou, A. \& Wilder, C. (eds.), Possessors, Predicates and Movement in the Determiner Phrase : 17-53. Amsterdam : John Benjamins.

Cardinaletti, Anna (2002). Towards a Cartography of Subject Positions. In Belletti,

A. \& Rizzi, L. (eds.), Proceedings of the Workshop on theCartography of Syntactic Positions and Semantic Types. Certosa Di Pontignano.

Cardinaletti, Anna ; Starke, Michal (1994). The Typology of Structural Deficiency : A Case Study of the Three Classes of Pronouns. In Riemsdijk, H. van (ed.), Clitics in the Languages of Europe, vol. 8 of Language Typology. Berlin : Mouton de Gruyter.

Cinque, Guglielmo (1994). On the Evidence for Partial N-Movement in the Romance DP. In Cinque, G., Koster, J., Pollock, J.-Y., Rizzi, L., \& Zanuttini, R. (eds.), Paths Towards Universal Grammar : Studies in Honor of Richard S. Kayne : 85-110. Washington, DC : Georgetown University Press.

Déchaine, Rose-Marie ; Wiltschko, Martina (2002). Decomposing Pronouns. Linguistic Inquiry $33:$ 409-442.

DiKKEN, Marcel den (1998). (Anti-)agreement in DP. In Bezooijen, R. van \& Kager, R. (eds.), Linguistics in the Netherlands : 95-107. 
DikKEN, Marcel den (1999), On the Structural Representation of Possession and Agreement : the Case of (Anti-)agreement in Hungarian Possessed Nominal Phrases. In Kenesi, I. (ed.), Crossing Boundaries : Advances in the Theory of Central and Eastern European Languages : 137-179. Amsterdam : John Benjamins.

Giorgi, Alessandra ; Longobardi, Giuseppe (1991). The Syntax of Noun Phrases. Cambridge : Cambridge University Press.

Hoekstra, Teun (1999). Parallels between Nominal and Verbal Projections. In Adger, D. (ed.), Specifiers : Minimalist Approaches : 163-187. Oxford : Oxford University Press.

KAYNE, Richard S. (1975). French Syntax. Cambridge, MA. : MIT Press.

KAYNE, Richard S. (1989). Notes on English Agreement, CIEFL Bulletin, Hyderabad : 41-67.

KAYNE, Richard S. (1993). Toward a Modular Theory of Auxiliary Selection, Studia Linguistica $47: 3-31$.

KAYNE, Richard S. (1994). The Antisymmetry of Syntax. Cambridge, MA. : MIT Press.

KAYNE, Richard S. (2000). Parameters and Universals. New York : Oxford University Press (chapter 8 : "Person Morphemes and Reflexives").

LONGOBARDI, Giuseppe (1994). Proper Names and the Theory of N-Movement In Syntax and Logical Form. Linguistic Inquiry 25 : 609-665.

LONGOBARDI, Giuseppe (2004). On the Syntax of Denoting. Paper presented at Copenhagen Symposium on Determination.

MuYSKEN, Pieter (1984). The Spanish that Quechua Speakers Learn : L2 Learning as Norm-Governed Behavior. In Andersen, R.W. (ed.) Second Languages : A Cross-Linguistic Perspective : 101-119. Rowley, MA. : Newbury House.

Picallo, Carme (1994). Catalan Possessive Pronouns : the Avoid Pronoun Principle Revisited. Natural Language and Linguistic Theory 12 : 259-299.

RitTER, Elizabeth (1995). On the Syntactic Category of Pronouns and Agreement. Natural Language and Linguistic Theory 13 : 405-443.

SÁNCHEZ, Liliana (1995). Aspectual Adjectives and the Structure of DP and VP. Probus 7 :167-180.

SÁNCHEZ, Liliana (1996). Syntactic Structures in Nominals : A Comparative Study of Spanish and Southern Quechua. Ph.D. dissertation, University of Southern California.

Szabolcsi, Anna (1981). The Possessive Construction in Hungarian : A Configurational Category in a Non-Configurational Language. Acta Linguistica Academiae Scientiarum Hungaricae 31 : 261-289.

Szabolcsi, Anna (1983). The Possessor that Ran Away from Home. The Linguistic Review $3: 89-102$.

Li waibe del croejhete walone. Remarques sur l'emploi de certaines prépositions. http://users.skynet.be/bs302306/croejh/node96.html : p5. 


\section{RÉSUMÉ}

Les constructions possessives de l'anglais, de l'espagnol et du français se distinguent par plusieurs propriétés. Cet article examine les variations concernant l'ordre des mots, l'expression de l'accord ainsi que la présence ou absence d'une préposition. Cet article étend l'analyse proposée pour l'anglais par Bernstein \& Tortora (2005) à l'espagnol et au français, reprenant en particulier l'idée que les possessifs prénominaux sont distincts des possessifs postnominaux. Dans les trois langues, on retrouve un possessif prénominal qui est incompatible avec l'article défini, ce qui constitue un argument en faveur de l'idée que les possessifs prénominaux occupent une position interne au DP. Les possessifs postnominaux ont des comportements hétérogènes à travers les langues. Le fait que of apparaisse en anglais est compatible avec l'idée (voir Kayne 1993) que le mouvement postulé est interne au DP. Ce raisonnement s'applique également aux constructions possessives avec des DP pleins en espagnol et en français, qui sont introduites par la préposition de. En espagnol, la préposition n'apparaît pas avec les pronoms possessifs postnominaux, qui se comportent comme des adjectifs prédicatifs. L'analyse proposée ici postule une structure de relative réduite avec un adjectif possessif et un complémenteur supprimé. En français, la préposition à apparaît avec un pronom nonpossessif. Cependant, il existe des arguments en faveur de l'idée que la construction du français a la même structure que celle de l'anglais.

\section{MotS-CLÉS}

Possessifs, adjectifs, pronoms, accord, génitif partitif, complexité morphologique, préposition. 